\title{
Financial Integration, Exchange Rate Stability and Macroeconomic Variables in Nigeria: "A Structural Impact"
}

\author{
Anuli Regina Ogbuagu ${ }^{1} \&$ Dennis Brown Ewubare ${ }^{2}$ \\ ${ }^{1}$ Department of Economics and Development Studies, Federal University, Ndufu -Alike Ikwo, Ebonyi State, Nigeria \\ ${ }^{2}$ Department of Agriculture and Applied Economics/ Ext, Rivers State University of Science and Technology, Port \\ Harcourt, Nigeria \\ Correspondence: Anuli Regina Ogbuagu, Department of Economics and Development Studies, Federal University, \\ Ndufu -Alike Ikwo, Ebonyi State, Nigeria. E-mail: anulireg@gmail.com
}

Received: August 8, 2015

Accepted: August 27, 2015

Online Published: September 4, 2015

doi:10.5430/rwe.v6n3p36

URL: http://dx.doi.org/10.5430/rwe.v6n3p36

\begin{abstract}
This paper explores the structural impact of financial integration and exchange rate stability on macroeconomic variables (inflation, economic growth, inflation volatility, and growth volatility) in Nigeria from 1980 to 2012, using a structural model. The study employs the use of Vector Error Correction Model (Coefficient Diagnostic Wald Test, and Impulse Response Function of VECM) to achieve our objectives. Time series data was collected from World Bank Development Indicators, Central Bank of Nigeria bulletin (2012) and Azienman, Chinn and Ito (2013). Results indicates that exchange rate stability has no significant impact on inflation rate in the short run, while percentage increase in financial integration has a significant reduction impact on the rate of inflation in lag $1 \& 2$ by $126 \%$ and $79 \%$ respectively. Again a percentage increase in exchange rate stability significantly increased economic growth in lag $1 \& 2$ by $30 \%$ and $50 \%$ respectively, while financial integration together with the financial institution depth (money supply/GDP) and financial market depth (stock market capitalization/GDP) have no significant impact on economic growth. Furthermore, there is no significant impact of the financial integration and exchange rate stability on inflation and growth volatility in the short-run. Exchange rate stability transmitted positive shocks to economic growth and inflation volatility and negative shocks to inflation rate and growth volatility. The impulse response of inflation and economic growth to a unit shock from financial integration fluctuated for the periods, while shocks from financial integration emitted negative impulse on inflation and growth volatility. In addition, impulse response of exchange rate stability and financial integration to unit shock from inflation, growth volatility and financial sector development (stock market capitalization/GDP, money supply/GDP) remained negative. The results imply that the combination of financial integration and exchange rate stability policy is a viable instrument towards achieving a stable economy. Therefore, this paper suggests that government should pay closer attention towards policies that will ensure stability in socio-economic and political environment, if Nigeria will achieve greater benefits in exchange rate stability and more financial integration.
\end{abstract}

Keywords: financial integration, exchange rate stability, inflation, economic growth, volatility, financial institution depth, financial market depth

\section{Introduction}

The inter-connectivity between financial globalization and exchange rate stability has been a policy concern for many developing countries, because the more integrated an economy becomes, the more it faces a choice between monetary autonomy and exchange rate stability. The exchange rate is one of the key international aggregate variables and the choice of exchange rate system overtime has become a policy question. There are both theoretical and empirical reasons to expect globalization to heighten the importance of the exchange rate. Theoretically, open-economy macroeconomic principles imply that capital mobility profoundly affects exchange rate policy choices (Frieden, 2010). In order to ensure currency stability countries have been experimenting with different exchange rate policy since early 1970s with the collapse of the Bretton-Woods fixed exchange rate system; some have implemented fixed exchange rate; fixed with the major trading partners, fixed within an agreed band, others have implemented crawling peg, most developed countries have allowed their currencies to float (pure), nonetheless some countries do apply a semi-fixed or semi-floating exchange rate system/dirty float- in which exchange rates are 
adjusted on a regular basis by the central bank, these types provide an intermediate degree of autonomy for the central bank.

It is obvious that given the globalization driven structural changes, the choice and implementation of exchange rate policies have to be reconsidered because government/ policy makers are highly constrained in the choice between choosing exchange rate and monetary autonomy and these choice are highly dependent on the level of financial integration. These constraints mean that the economics and politics of monetary and exchange rate policy are likely to be very different in an economy that is financially open than in an economy that is not (Frieden 2010)

Alongside globalization quest, many countries have suffered because of poor economic policy regimes, and this shortcoming reduces their capacity to successfully compete globally (Schneider and Enste, 2002). Since the inception of financial globalization in mid 1980, there are significant arguments for a positive impact of integration with the international capital market, especially for developing countries. Financial integration among economies is believed to have two positive impacts. It can improve the allocative efficiency of capital, facilitates risk-sharing and thereby enhance production specialization, capital allocation, and ultimately economic growth (Obstfeld 1994). Levine (2001) indicated that financial integration helps to strengthen domestic financial sector allowing for more efficient capital allocation, greater investment and growth opportunities. Likewise, financial integration can help capital-poor countries diversify away from their production bases that mostly depend on agricultural activities or extractions of natural resources; this diversification should reduce macroeconomic volatility (Kose et al., 2006). For example, in Chile, Korea, and Mexico are some examples where liberalization has produced a positive result with the integrated approach (IMF, 2012).

In order to fully achieve the benefits accruing from globalization/ integration, some countries have struggled on how to simultaneously achieve exchange rate stability, monetary autonomy and financial integration as major economic policies to ensure reduced macroeconomic volatility and stimulate a sluggish economy. The trilemma of international economics and finance suggests that only two of these three policies can be achieved simultaneously (Ghosh et al., 1997; Edison et al.2002, Aizenman et al., 2008b, 2011a; Aizenman and Ito, 2012). For example Australia achieves independent monetary policy and free capital flows and allows the exchange rate to fluctuate based on market forces. China achieves monetary autonomy and exchange rate stability and imposes some controls on capital mobility. Hong Kong pursues exchange rate stability and free capital flows and abandons its ability to maintain an independent interest rate policy. Also many few empirical studies have attempted to use the trilemma index to examine the impact on macroeconomic variables. For example Alexiou 2011, Chinn and Ito, (2006, 2008); Aizenman et al.( 2011b), Obstfeld et al., (2005), Aizenman et al., (2011a) Aizenman and Ito (2012) among others.

As disclosed by Obadan (2006), Nigeria is one of the countries that operate managed floating exchange rate system called "dirty float". Based on the above, this paper assumes that Nigeria have little monetary autonomy. Therefore in the context of Trilemma, we examine the impact of exchange rate stability and financial integration on some selected macroeconomic variables (inflation, economic growth, inflation volatility, growth volatility).

The objectives of this paper are in two folds and they are;

(1) To examine the long run and short run impact of financial integration and exchange rate stability on selected macroeconomic variables (inflation, economic growth, inflation volatility, growth volatility)

(2) To explore the impulse response of inflation, economic growth, inflation volatility, and growth volatility to a unit shock from policy variables (financial integration and exchange rate stability).

This study is justified by the fact that no previous studies has examined the relationships between the international policy variables (Trilemma) and macro-economy in Nigeria, again most of the study are cross-country analysis. Therefore this will be one of the foremost study on the impact of trilemma index on a single country (Nigeria) using the well developed index by Aizenman, Chinn and Ito (2013).

To achieve these objectives, our hypotheses are developed as:

$\mathrm{Ho}_{1}$ : there is no significant long/ short run impact of financial integration and exchange rate stability on inflation, economic growth, inflation volatility, growth volatility.

Ho2: financial integration and exchange rate stability has no significant growth responses on (inflation, economic growth, inflation volatility, growth volatility in Nigeria.

\section{Theoretical and Empirical Literature}

> The "Impossible Trinity" or "Trilemma": Theory and Evidence 
Trilemma is an index developed by Aizenman, Chinn and Ito in 2010 that measures the degree of achievement in each of the three policy choices (financial integration, exchange rate stability and monetary autonomy) for a wide coverage of 170 countries. The hypothesis in international finance is that policy makers must face a trade-off of choosing two, not all, of the three policy choices: monetary independence, exchange rate stability, and financial openness.

According to Azienmen, Chinn and Ito (2012), the impossibility of using or achieving greater result in all the three policy variables simultaneously is displayed with the figure below;

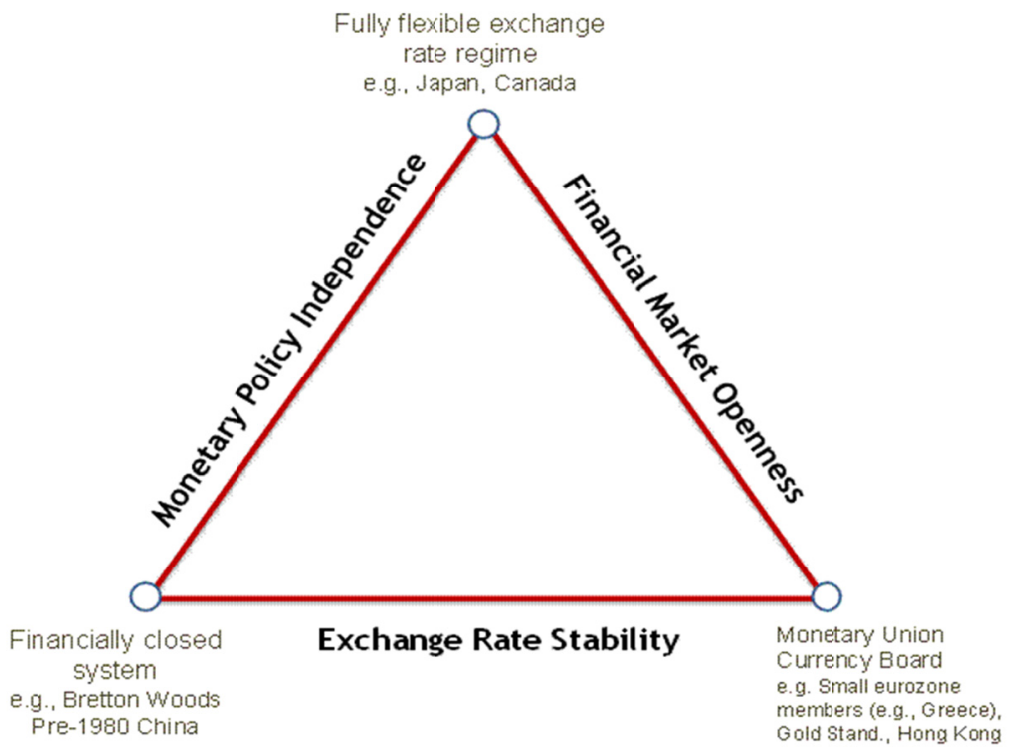

Source: Azienman Chin and Ito (2012)

Figure 1. The trade-off between the three policy variables (exchange rate stability, financial integration, and monetary independence as developed by Azienman, chin and Ito (2012)

The trilemma is illustrated in Figure 1. Each of the three sides of the triangle-representing monetary independence, exchange rate stability, and financial integration-depicts a potentially desirable goal, yet it is not possible to be simultaneously on all three sides of the triangle. For example, the top vertex, labeled - floating exchange rate, is associated with the full extent of monetary policy autonomy and financial openness, but not exchange rate stability (Azienman, Chin and Ito, 2012) and so on.

History has shown that different international financial systems have attempted to achieve combinations of two out of the three policy goals, such as the Gold Standard system - guaranteeing capital mobility and exchange rate stability - and the Bretton Woods system - providing monetary autonomy and exchange rate stability. The fact that economies have altered the combinations as a reaction to crises or major economic events may be taken to imply that each of the three policy options is a mixed bag of both merits and demerits for managing macroeconomic conditions. Greater monetary independence could allow policy makers to stabilize the economy through monetary policy without being subject to other economies' macroeconomic management, thus potentially leading to stable and sustainable economic growth. Furthermore, monetary authorities could also abuse their autonomy to monetize fiscal debt, and therefore end up destabilizing the economy through high and volatile inflation (Azienman, chin and Ito, 2012).

There have been various literatures that have attempted to examine the policy issues of Trilemma, and all came out with mixed results. For example, Aizenman et al., (2008b) using a large sample including Greece, indicate that for developing countries, increased monetary independence results in higher inflation, and more exchange rate stability results in higher inflation and output volatility. Aizenman et al., (2011a) shows that more exchange rate stability or more financial integration reduces inflation whereas more monetary autonomy raises inflation and more exchange rate stability increases output volatility and investment volatility whereas more monetary autonomy reduces output volatility. Aizenman and Ito (2012) reveal that the three trilemma policies in emerging economies are converging 
toward a middle ground as they pursue managed floating exchange rates backed up by large foreign reserves, moderate monetary autonomy, and medium level financial integration. These emerging economies experience less output fluctuations whereas emerging economies with relatively low foreign reserves as a percent of GDP would suffer relatively high output fluctuations if they select policy divergence. Based on a multi-country sample including Greece, Obstfeld et al., (2005) finds that countries can consider the trilemma as a guiding macroeconomic policy framework. Countries with floating exchange rates and free capital flows would retain sufficient amount of monetary independence whereas countries with pegging exchange rates and free capital mobility would lose significant amount of monetary independence.

Aizenman et al (2010) using the "trilemma indexes" examines how policy configuration affects macroeconomic performances, with focus on the Asian economies. They found that the three policy choices matter for output volatility and the medium-term level of inflation. Greater monetary independence is associated with lower output volatility while greater exchange rate stability implies greater output volatility, which can be mitigated if a country holds international reserves (IR) at a level higher than a threshold (about $20 \%$ of GDP). Greater monetary autonomy is associated with a higher level of inflation while greater exchange rate stability and greater financial openness could lower the inflation rate.

Yu Hsing (2012) finds support for the trilemma for Greece, implying that there is a tradeoff among exchange rate stability, monetary independence and financial integration. The policy combination of monetary independence and financial integration has been prevalent. More exchange rate stability does not affect the inflation rate, the growth rate, inflation volatility and output volatility. More monetary independence reduces output volatility. More financial integration reduces inflation, inflation volatility and output volatility. Hence, more financial integration or monetary independence is beneficial to Greece. And Hutchison et al (2012) calculates a trilemma index for India and investigates its evolution over time and find that financial integration has increased markedly after the mid-2000s, with corresponding limitations on monetary independence and exchange rate stability. This tradeoff has been mitigated, however, with the rise of international reserves as a partially independent instrument of macroeconomic policy. In addition, they confirm that the weighted sum of the three indexes adds up to a constant, validating the notion that a rise in one trilemma variable should be traded-off with a drop of the weighted sum of the other two. Finally, they consider the implications of changes in the trilemma index for macroeconomic outcomes. They find some evidence that greater financial integration and corresponding loss of monetary autonomy and exchange rate stability has influenced inflation and inflation volatility, though not in a consistent manner.

\subsection{Exchange Rate Stability/ Theories}

Exchange rate policy in Nigeria has undergone substantial transformation since the post-independent era between $17^{\text {th }}$ to $19^{\text {th }}$ century various exchange rate policy have evolved overtime; starting from early 1970 when exchange rate was fixed in consonance with International Monetary Fund (IMF) par value to the 1978 - when it was pegged to a basket of 12 currencies comprising Nigeria's major trading partners. And then from 1986 when market-based exchange rate system was introduced in the context of the Structural Adjustment Programme (SAP). This policy was jettisoned in 1985 in favour of quoting the naira against the dollar. And all these policy changes have its objectives.

Under the SAP which was implemented from July 1986, the exchange rate strategy was to float the naira and establish an institutional framework for its trading in a market - determined environment. And the objective was pursued within the institutional framework of the second-tier foreign exchange market S(FEM). The S(FEM) was expected to evolve an effective mechanism for exchange rate determination and allocation of foreign exchange in order to guarantee short-term stability and long-term balance of payment equilibrium. The exchange rate system at this time was dual policy. Thus, Nigeria exchange rate management after 1986 could be categorized as "managed Float" in which the Central Bank of Nigeria (CBN) embarked on a delicate balancing act of controlling volume and price till date (Nnana 2002)

Using the exchange rate stability index developed by Azienman, Chinn and Ito in 2008 and upgraded in 2012, the figure below shows a graphical representation of the level of achievement in stabilizing Nigerian exchange rate from 1980 to 2012. 


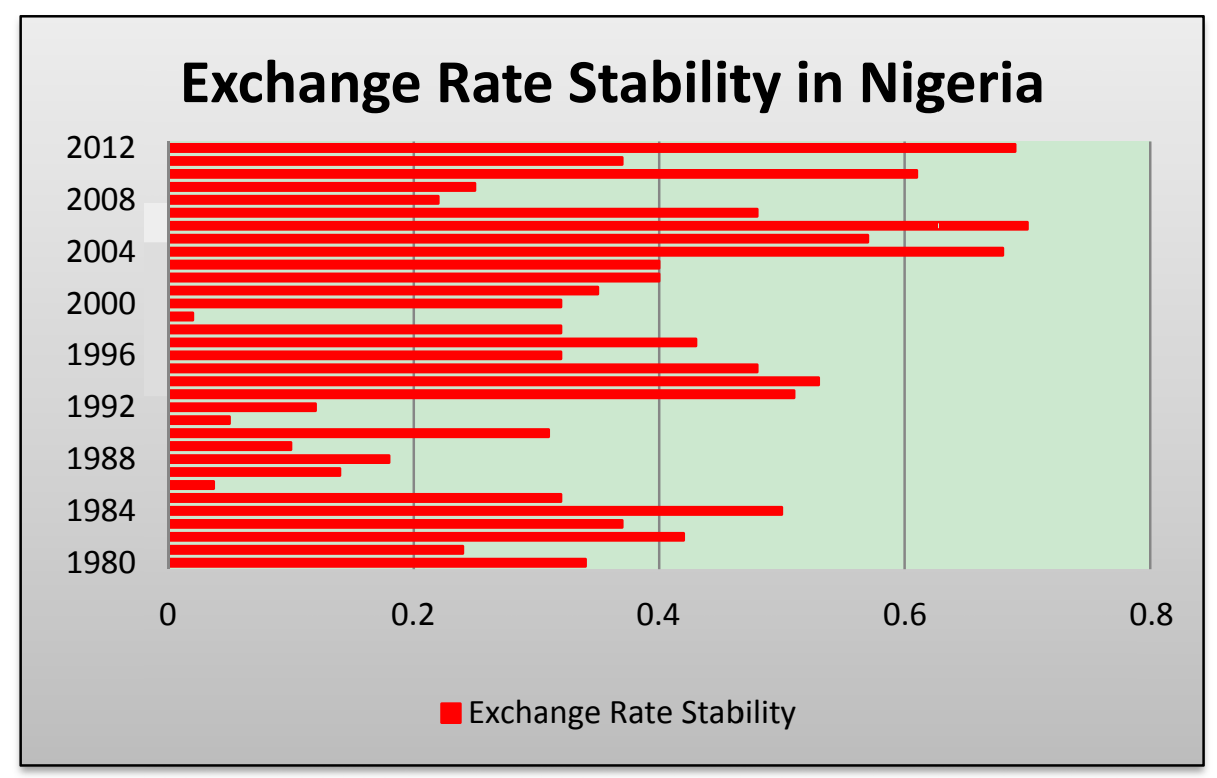

Data Source: Trillema index (2012)

Figure 2. Graphical representation of exchange rate stability in Nigeria $(1980-2012)$

The Figure above displayed the extent of achievement in exchange rate stability from 1980 to 2012, using data from Trillema index developed by Aizenman, Chin and Ito 2008 and updated in 2012. For Nigerian economy, so far the main objective of all the exchange rate policies is to achieve and ensure stability in exchange rate. And figure 2, showed that exchange rate stability index fluctuated all through the periods. Starting from 1980 with the value 0.3432 to 1986 with the value 0.0372 , the value fluctuated through the years till 2006 with the highest value of 0.7048 .

More exchange rate stability is expected to stabilize the currency value and price level, reduce uncertainty, and help economic growth. On the other hand, more exchange rate stability may increase or reduce inflation or inflation volatility, depending upon whether the pegged anchor currency would appreciate, depreciate or be volatile (Hsing 2012). In Mundell (1973a, 1973b) exchange rate movements do not stabilize the economy in the face of asymmetric shocks. Instead, they are independent sources of volatility because foreign exchange markets are not efficient. They are dominated by speculative dynamics that lead to exchange rate movements unconnected to movements in the fundamentals. As a result, exchange rates exhibit excess volatility and are a source of great macroeconomic volatility, especially in small, open economies. In this world it is beneficial for small, open economies that allow the free movement of capital to fix their exchange rates as a way to avoid the disruptive macroeconomic effects of floating exchange rates (Hsing 2012).

\subsection{Exchange Rate Regime and Inflation}

The predominant view on the relationship between the exchange regime and inflation is that pegged exchange rates contribute to lower and more stable inflation. For (developing and emerging) countries with (comparatively) weak institutional frameworks, pegged exchange rates provide an important tool to control inflation via both a commitment toward exchange rate stability and a disciplining effect on monetary growth (Crocket and Goldstein, 1976). For small, open economies, pegging the nominal exchange rate helps minimize fluctuations of the domestic price level and thereby contributes to macroeconomic stability (McKinnon, 1963). In contrast, in countries with strong institutional frameworks (based on central bank independence and developed money markets), low inflation can be achieved without any specific commitment to an explicit exchange rate target (Calvo and Mishkin, 2003). Recently, inflation targeting frameworks have become a widely used tool to achieve price stability in both industrial countries and emerging markets. In large (closed) economies, inflation targets - which imply freely floating exchange rates - will not affect the volatility of inflation, because the fraction of traded goods on the aggregate price level is comparatively small. In contrast, in smaller (more open) economies, exchange rate fluctuations might impair price stability, and therefore (informal) exchange stabilization might persist. Grauwe and Schnabl (2006) found 
significant impact of exchange rate stability on low inflation as well as a highly significant positive impact of exchange stability on real growth.

\subsection{Exchange Rate Regime and Output Growth}

Since economic theory does not allow us to make precise predictions, the question of whether exchange rate stability leads to more or less economic growth is essentially an empirical matter. Proponents of fixed exchange rates have argued that stable exchange rates foster economic growth by promoting macroeconomic stability, in particular in small, open economies. McKinnon and Schnabl (2004) argue for East Asia that until the Asian crisis exchange rate stability against the U.S. dollar contributed to low and stable inflation as well as to sound government finance. The resulting stable expectations in turn promoted investment and long-term growth (the East Asian miracle). One can identify two reasons why exchange rate stability promotes higher economic growth. First, the elimination of foreign exchange risk stimulates international trade and thereby the international division of labor. While the evidence for the positive impact of exchange rate stability on trade has remained mixed, recently, Frankel and Rose (2002) have found a strong positive impact of irrevocably fixed exchange rates on trade and income in the context of a monetary union. Second, credible fixed exchange rate regimes create an environment of macroeconomic stability, thereby reducing the risk premium embedded in the real interest rate. In contrast to this view, Meade (1951) and Friedman (1953) have argued that under flexible exchange rates, countries can adjust to real shocks more easily. Under fixed exchange rate regimes, real exchange rate adjustments must be carried out through relative price changes, which in a world of price rigidities is slow and costly. This may create an excessive burden on the economy, leading to slow economic growth. Comparing growth in industrial countries during and after the BrettonWoods System, Mundell (1995) finds faster growth in times of exchange rate stability.

\subsection{Financial Integration}

Financial integration is the process through which financial markets in an economy become more closely integrated with those in other economies or with those in the rest of the world. This implies an increase in capital flows and a tendency for prices and returns on traded financial assets in different countries to equalize (De Brouwer 2005).

According to Ho (2010), "financial integration could proceed with enforcement of a formal international treaty. This refers to two distinct elements. One is the provision for concerted or cooperative policy responses to financial disturbances. The other is the elimination of restrictions on cross-border financial operations by member economies, as well as harmonization of regulations of financial systems to achieve full unification of regional financial markets, and taxes and regulations between member economies". And it is expected that in theory, financial globalization can help developing countries to better manage output and consumption volatility. Indeed, a variety of theories imply that the volatility of consumption relative to that of output should decrease as the degree of financial integration increases; the essence of global financial diversification is that a country is able to shift some of its income risk to world markets. Since most developing countries are rather specialized in their output and factor endowment structures, they can, in theory, obtain even bigger gains than developed countries through international consumption risk sharing - that is, by effectively selling off a stake in their domestic output in return for a stake in global output (Kose et al, 2004).

Since late 1970s there is increase in the wave of financial globalization, eventually the 1980s and 1990s saw a significant increase in financial integration (Lothian, 2000); this increased financial integration generates a great deal of cross-border capital flows among industrial nations and between industrial and developing countries. In addition, this increase in financial integration pulls global financial markets closer together and escalates the presence of foreign financial institutions across the globe. With rapid capital flows around the world, the currency and financial crises in the late 1980s and 1990s were inevitable. Consequently, developing countries that welcomed excessive capital flows were more vulnerable to these financial disturbances than industrial nations. It is widely believed that these developing economies were much more adversely impacted as well.

There has been a heated debate among both academics and practitioners' concerning the costs and benefits of financial integration and this debate is ongoing (Kose et al., 2006).

Benefits of financial integration include efficient capital allocation, better governance, higher investment and growth, and risk-sharing. Levine (2001) shows that financial integration helps strengthen domestic financial sector allowing for more efficient capital allocation and greater investment and growth opportunities. As a result of financial integration, efficiency gains can also be generated among domestics firms because they have to compete directly with foreign rivals; this competition can lead to better corporate governance (Kose et al., 2006). If having access to a broader base of capital is a major engine for economic growth, then financial integration is one of the solutions 
because it facilitates flows of capital from developed economies with rich capital to developing economies with limited capital. These capital inflows can significantly reduce the cost of capital in capital-poor economies leading to higher investment (Kose et al., 2006). Likewise, financial integration can help capital-poor countries diversify away from their production bases that mostly depend on agricultural activities or extractions of natural resources; this diversification should reduce macroeconomic volatility (Kose et al., 2006). Beside Financial integration can also have adverse effects. For example, a higher degree of financial integration can generate a severe financial contagion in neighboring, regional and/or global economies. In addition, Boyd and Smith (1992) argue that capital outflows can journey from capital-poor countries with weak institutions and policies to capital-rich countries with higher institutional quality and sound policies. Consequently, financial integration actually hurts capital-scarce countries with poor institutional quality and lousy policies. Eichengreen (2001) concludes that the findings in literature are ambiguous on evidence that liberalization has any impact on growth. While Kose et al (2006) reports that the majority of studies, however tend to find no effect or at best a mixed effect for developing countries. But Behera and Ranjan (2009) using panel cointegration test, found a long run relationship between per capital income and financial globalization. There are a lot of empirical literatures on the issues of financial integration across the globe; Baxter and Crucini (1995) find that the volatility of output increases while the volatility of consumption (and the relative volatility of consumption) decreases with rising financial integration. The relationship between financial openness and macroeconomic volatility could also be affected by the structural characteristics of developing countries, which make them more vulnerable to shocks originating in other countries. First, limited diversification of exports and imports make some of these countries particularly susceptible to sudden fluctuations in terms of trade and foreign demand shocks. Second, sudden changes in the direction of capital flows are able to induce boom-bust cycles in developing countries, most of which do not have deep financial sectors to cope with the highly volatile capital flows. Third, country size is an important factor and developing economies are relatively much smaller than industrialized countries. Kose and Prasad (2002) find that both terms of trade shocks and foreign aid flows are particularly important in accounting for highly volatile macroeconomic fluctuations in small states (defined as countries with a population below 1.5 million), which seem to exhibit higher degrees of trade and financial openness than do other developing countries. Likewise Quinn (1997) shows that capital account openness is robustly positively correlated with long-run economic growth in 64 countries for 1958 to 1989, whereas Arteta et al. (2001) indicate that capital account liberalisation is as likely to hurt as to help growth.

Since the liberalization in Nigeria in 1995, many years have passed; the figure below shows the extent of achievement in opening up the economy to the rest of the world;

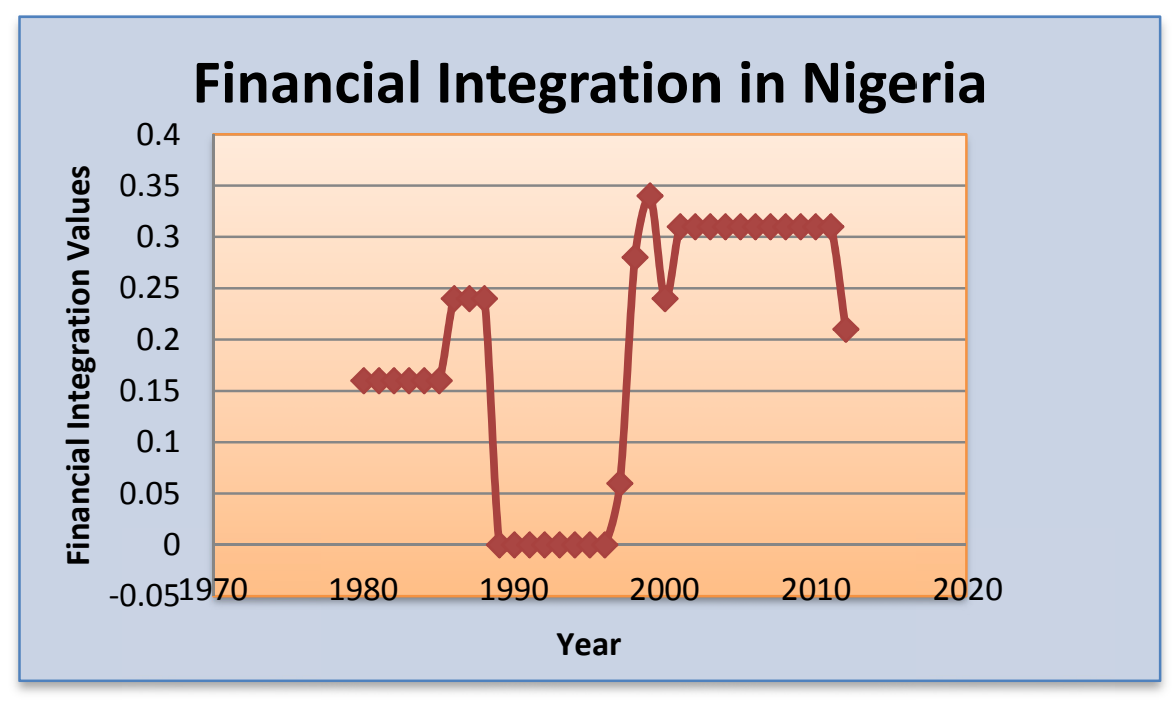

Data Source: Trillema index (2012)

Figure 3. Graphical representation of financial integration index $(1980-2012)$ for Nigeria 
The Figure3 above displayed the extent of achievement in Financial Integration from 1980 to 2012, using data from Trillema index developed by Aizenman, Chin and Ito 2008 and updated in 2012.

\section{Model Specification}

Taking a lead from previous studies by Aizenman et al., (2008b, 2011a), Aizenman, Chin and Ito (2012) and Aizenman et al (2012), this work is basically modeled after Hsing (2012).

We can express the trilemma equation as:

$$
K=f\left(E S_{t}, M I_{t}, F I_{t}\right)
$$

$\mathrm{K}=\mathrm{a}$ constant, (which is the dependent variable)

$\mathrm{ES}=$ exchange rate stability,

$\mathrm{MI}=$ monetary independence, and

FI = financial integration or free capital mobility

If the goodness of fit is relatively high, it suggests that these three policies are binding and constrained. An increase in the value of one of the trilemma policies will reduce the value of one or both of the other policies. Note that equation (1) is written in the general form because other functional forms will be considered and tested (Hsing, 2012).

According to Aizenman et al. (2008) "these three measures of the trilemma are linearly related. Therefore, it is most appropriate to include two of the indexes simultaneously, rather than individually or all three jointly. This means, as theory predicts, economies do face the trade-off of the three policy choices". Based on the fact that Nigeria has little monetary autonomy, we choose the policy combination of financial integration and exchange rate stability for Nigeria.

The estimation model is given by:

$$
\begin{gathered}
\mathrm{Y}_{\mathrm{t}}=\mathrm{f}(\mathrm{ESFI}, \mathrm{CONT}) \\
\mathrm{Y}_{\mathrm{t}}=\beta_{0}+\beta_{1} \mathrm{ES} \mathrm{FI}_{\mathrm{t}}+\beta_{2} \text { CONT }_{\mathrm{t}}+\varepsilon_{\mathrm{t}}
\end{gathered}
$$

$\mathrm{Y}_{\mathrm{t}}$ represents any of the macroeconomic variables - the dependent variables (inflation, inflation volatility, economic growth, growth volatility)

ESFI stands for the vector of the two of the three trilemma indexes namely; (Exchange rate stability and financial integration), CONT denotes macroeconomic control variables - that include the variables most used in the literature [financial market depth (Stock Market Capitalization ratio to GDP) and financial institution depth (money supply ratio to GDP)]

\subsection{Functional Specification}

We test potential impacts of exchange rate stability, and financial integration on the inflation rate, the growth rate of real GDP, inflation volatility and growth volatility. In order to take care of the presence of white noise, we introduce the error term which transforms the mathematical model to an econometric model as specified in equation (4) below:

$$
Y_{t}=\beta_{0}+\beta_{1} \operatorname{exrs}_{t}+\beta_{2} \text { fini }_{t}+\beta_{3} \text { smcap }_{t}+\beta_{4} \text { msup }_{t}+\mu_{t}
$$

Where $\mu_{t}=$ the white noise, $\beta_{s}$ are the model parameters, $\mathrm{t}$ is current year. Yt represents any of the macroeconomic variables - the dependent variables;Inflation, economic growth, inflation volatility, and growth volatility. Therefore, our estimated equations are thus;

$$
\begin{aligned}
& \text { Cpint }=\text { bot }+ \text { b1exrst }+ \text { b2finit }+ \text { b3rgdpt }+ \text { b4smcapt }+ \text { b5msupt }+\mu \mathrm{t} \\
& \text { rgdpt }=\text { bot }+ \text { b1exrst }+ \text { b2finit }+ \text { b3Cpint }+ \text { b4smcapt }+ \text { b5msupt }+\mu \mathrm{t} \\
& \text { cpivt }=\text { bot }+ \text { b1exrst }+ \text { b2finit }+ \text { b3gdpvt }+ \text { b4smcapt }+ \text { b5msupt }+\mu t \\
& \text { gdpvt }=\text { bot }+ \text { b1exrst }+ \text { b2finit }+ \text { b3cpivt }+ \text { b4smcapt }+ \text { b5msupt }+\mu \mathrm{t}
\end{aligned}
$$

\subsection{Method of Data Analysis and Time Series Property of Data Used}

The methodology applied in this study following the literature is based on time series data sets. The estimation procedure adopted in deriving the estimates of the parameters of economic relationships is the Ordinary Least Squares (OLS). E-View 5 was used to run the regression. 


\subsubsection{Check for Stationarity and Cointegration}

\section{$>$ Unit-Root Test:}

There often exists the problem of non-stationarity in empirical research involving time series data and this renders the traditional tools of econometrics (like OLS) inappropriate. To overcome unit-root problem, we test for stationarity of the series in use. The Augmented Dickey-Fuller test (ADF) is of choice in this study because of its efficiency in detecting unit root. It is specified as follows:

$$
\Delta Y_{t}=\theta_{o}+\theta_{1} Y_{t-1}+\sum_{i=1}^{k} b_{i} \Delta Y_{t-i}+\mu_{t}
$$

Where, $Y_{t}$ is a vector of all variables in the model $\theta_{i}$ and $b_{i}$ are parameters of the model, $\mu_{\mathrm{t}}$ is the white noise at time while $k$ and $\Delta$ remain as defined in equation (6) above. This we will achieve, conducting the test by first or second level difference if the series are integrated of order one or order two (i.e. I(1) or I(2)). The null hypothesis here is that $Y_{t}$ has a unit root (that is, non-stationary) and the alternative is that there is no unit root (that is, stationary). If the variables turn out to contain unit roots, we will therefore, conclude that they are non-stationary.

\subsubsection{Cointegration Test}

In time series analysis, we often encounter situations where we wish to model one non-stationary time series $\left(\mathrm{Y}_{t}\right)$ as a linear combination of other non-stationary time series $\left(\mathrm{X}_{1 \mathrm{t}}, \mathrm{X}_{2 \mathrm{t}}, \mathrm{X}_{\mathrm{Kt}}\right)$. In other words:

$$
\mathrm{Y}_{\mathrm{t}}=\beta_{\mathrm{o}}+\beta_{1} \mathrm{X}_{1 \mathrm{t},}+\beta_{2} \mathrm{X}_{2 \mathrm{t},},+\ldots+\beta_{\mathrm{k}} \mathrm{X}_{\mathrm{Kt}}+\varepsilon_{\mathrm{t}}
$$

In general, a regression model for non-stationary time series variables gives spurious (nonsense) results. The only exception is if the linear combination of the (dependent and explanatory) variables eliminates the stochastic trend and produces stationary residuals.

$$
\mathrm{Y}_{\mathrm{t}}+\mathrm{Y}_{1} \mathrm{X}_{1 \mathrm{t},}+\mathrm{Y}_{2} \mathrm{X}_{2 \mathrm{t},},+\ldots+\mathrm{Y}_{\mathrm{k}} \mathrm{X}_{\mathrm{K}, \mathrm{t}} \sim 1(0)
$$

In this case, we refer to the set of variables as cointegrated. It is only in this case that we can look at regression as a reasonable and reliable model.

\subsubsection{Econometric Procedural (Test)}

$>$ Breusch-Godfrey Serial Correlation LM test; test for autocorrelation.

$>$ Arch LM Test for Heteroscedasticity

$>$ And Jarque - Bera to check whether the residuals are normally distributed

\subsection{Method for Evaluation (Structural Model)}

\section{$>$ Vector Error Correction Model (VECM) for Objective 1}

A vector error correction model (VECM) can lead to a better understanding of the nature of any non stationarity among the different component series and can also improve longer term forecasting over an unconstrained model.

The VECM form with the cointegration rank $r(\leq k)$ is written as

$$
\Delta \mathbf{y}_{t}=\boldsymbol{\delta}+\Pi \mathbf{y}_{t-1}+\sum_{i=1}^{p-1} \Phi_{i}^{*} \Delta \mathbf{y}_{t-i}+\boldsymbol{\varepsilon}_{t}
$$

Where $\Delta$ is the differencing operator, such that $\Delta \mathbf{y}_{t}=\mathbf{y}_{t}-\mathbf{y}_{t-1} ; \Pi=\alpha \beta^{\prime}$, where $\alpha$ and $\beta$ are $k \times r$ matrices; $\Phi_{i}^{*}$ is a $k \times k$ matrix.

It has an equivalent $\operatorname{VAR}(P)$ representation as described in the preceding section.

$$
\mathbf{y}_{t}=\boldsymbol{\delta}+\left(I_{k}+\Pi+\Phi_{1}^{*}\right) \mathbf{y}_{t-1}+\sum_{i=2}^{p-1}\left(\Phi_{i}^{*}-\Phi_{i-1}^{*}\right) \mathbf{y}_{t-i}-\Phi_{p-1}^{*} \mathbf{y}_{t-p}+\boldsymbol{\varepsilon}_{t}
$$

Where $I_{k}$ is a $k \times k$ identity matrix 


\section{Impulse Response Function (IRF) for Objective 2}

Impulse response function (IRF) is refers to the reaction of any dynamic/ structural system in response to some external change. In both cases, the impulse response describes the reaction of the system as a function of time (or possibly as a function of some other independent variable that parameterizes the dynamic behavior of the system). That is it identifies the responsiveness of the dependent variables (endogenous variable) in the VEC model when a shock is put to the error term such as $\mu \mathrm{t}(\mathrm{s})$.

\subsection{Source of Data}

Annual time series data used for the analysis was sourced from World Bank Development Indicators (2012), CBN statistical bulletin (2012), and Aizenman, Chinn and Ito (2013) for Trilemma Index, World Bank"s Global Financial Development Database (2010).

\subsection{Variable Description}

$>$ Trilemma Index

In macroeconomic management, policy makers must face a trade-off of choosing two, not all of the three policy choices; monetary independency, exchange rate stability, and financial openness. This is a famous hypothesis in international finance called the "trilemma" or the "impossible trinity".

History has shown that different international financial systems haven attempted to achieve combinations of two out of the three policy goals. For example, the Gold Standard system guaranteed capital mobility and exchange rate stability while the Bretton Woods system provided monetary autonomy and exchange rate stability (Aizenman, Chinn and Ito 2008).

\section{$>$ Financial Integration}

Financial liberalization is perhaps the most contentious and hotly debated policy among the three policy choices of the trilemma. On one hand more open financial markets could lead to economic growth by paving the way for more efficient resource allocation, mitigating information asymmetry, enhancing and/or supplementing domestic savings, and helping transfer of technological or managerial know-how (i.e., growth in total factor productivity). This variable is gotten from Aizenman, Chinn and Ito (2008).

\section{$>$ Exchange Rate Stability}

Exchange rate stability could bring out price stability by providing an anchor and lower risk premium by mitigating uncertainty, thereby fostering investment and international trade. Also, at the time of an economic crisis, maintaining a pegged exchange rate could increase the credibility of policy makers and thereby contribute to stabilizing output movement (Aizenman, et al., 2009). We used Aizenman, Chinn and Ito (2008) index.

$>$ Financial Development

Here we employ two variables as a measure of financial development; financial institution depth and financial market depth. The World Bank's Global Financial Development Database developed a comprehensive yet relatively simple conceptual $4 \times 2$ framework to measure financial development around the world. This framework identifies four sets of proxy variables characterizing a well-functioning financial system: financial depth, access, efficiency, and stability.

A large body of evidence suggests that financial sector development plays a huge role in economic development. It promotes economic growth through capital accumulation and technological progress by increasing the savings rate, mobilizing and pooling savings, producing information about investment, facilitating and encouraging the inflows of foreign capital, as well as optimizing the allocation of capital. Countries with better-developed financial systems tend to grow faster over long periods of time, and a large body of evidence suggests that this effect is causal: financial development is not simply an outcome of economic growth; it contributes to this growth.

Based on this, we use the ratio of money supply (M2) to GDP to measure the financial institution depth and stock market capitalization to GDP as a proxy for financial market depth.

\section{$>$ Inflation and inflation volatility}

A chief measure of price inflation is the inflation rate, the annualized percentage change in a general price index normally the consumer price index over time. To achieve our objective, we used five years standard deviation of the consumer price index for our time series data as a proxy for inflation volatility. A highly volatile rate of inflation has the potential to do great economic harm. With nominal contracts, uncertainty about future prices is likely to entail 
higher risk premia and unanticipated changes in the distribution of wealth. These costs mean that for a given average inflation rate, higher inflation volatility can depress economic growth (Elder, 2004; Grier and Grier, 2006).

\section{Economic Growth}

Is a macroeconomic measure of the value of economic output adjusted for price changes (ie; inflation). Economic growth is the increase in the market value of the goods and services produced by an economy over time. It is conventionally measured as the percent rate of increase in real gross domestic product, or real GDP. For growth volatility we used five years standard deviation of the real gross domestic product from the time series data.

\section{Presentation of Result and Interpretation}

$>$ Unit Root Test

As indicated in the literature, most time series variables are non-stationary and using non-stationary variables in the model might lead to spurious regressions. The first or second differenced terms of the most variables will usually be stationary. Hence, the variables were found significant at first differences.

\section{Johansen Cointegration Test}

Using Johansen cointegration both trace and maximum-eigenvalue indicates 2 cointegration(s) at 0.05 levels for our models.

\section{Vector Error Correction Model}

Model 1a

$$
\mathrm{Cpin}_{\mathrm{t}}=\mathrm{b}_{\mathrm{ot}}+\mathrm{b}_{1} \text { exrs }_{\mathrm{t}}+\mathrm{b}_{2} \text { fini }_{\mathrm{t}}+\mathrm{b}_{3} \text { rgdp }_{\mathrm{t}}+\mathrm{b}_{4} \text { smcap }_{\mathrm{t}}+\mathrm{b}_{5} \text { msup }_{\mathrm{t}}+\mu_{\mathrm{t}}
$$

Where rgdp, smcap, and msup are introduced in the model as control variables, $b_{t} s$ are the model parameters, $t$ is current year. Other variables remained as described in the equations above. And $\mu$ is equal to the white noise. Note that this model exhibit inflation as the dependent variable and the result is shown below.

Table1. VECM (dependent variable: $\mathrm{D}(\log c$ in $))$

\begin{tabular}{crcrc}
\hline \hline & Coefficient & Std. Error & t-Statistic & Prob. \\
\hline \hline C(1) & 0.163472 & 0.548478 & 0.298047 & 0.7700 \\
C(2) & -0.302614 & 0.155827 & -1.941994 & 0.0725 \\
C(3) & -0.120971 & 0.407900 & -0.296571 & 0.7711 \\
C(4) & -0.642535 & 0.336069 & -1.911913 & 0.0766 \\
C(5) & 0.015572 & 0.133262 & 0.116854 & 0.9086 \\
C(6) & -0.157330 & 0.112925 & -1.393220 & 0.1853 \\
C(7) & -1.266443 & 0.448430 & -2.824172 & 0.0135 \\
C(8) & -0.795326 & 0.533670 & -1.490296 & 0.1583 \\
C(9) & 0.027558 & 0.118640 & 0.232283 & 0.8197 \\
C(10) & -0.071700 & 0.135670 & -0.528488 & 0.6054 \\
C(11) & 0.062348 & 0.108435 & 0.574982 & 0.5744 \\
C(12) & -0.367089 & 0.115179 & -3.187109 & 0.0066 \\
C(13) & 0.232953 & 0.850410 & 0.273931 & 0.7881 \\
C(14) & 0.914776 & 0.828015 & 1.104782 & 0.2879 \\
C(15) & 0.044332 & 0.101388 & 0.437247 & 0.6686 \\
\hline \hline R-squared & 0.795772 & Mean dependent var & -0.022661 \\
Adjusted R-squared & 0.591543 & S.D. dependent var & 0.724792 \\
S.E. of regression & 0.463219 & Akaike info criterion & 1.605012 \\
Sum squared resid & 3.004011 & Schwarz criterion & 2.312234 \\
Log likelihood & -8.272679 & Durbin-Watson stat & 2.034137 \\
\hline \hline
\end{tabular}

Source: Authors e-view computation (2015) 
From the above table, the coefficient of cointegrating variable is not significant and is not negative indicating that there is no long run causality existing between the variables.

In the short-run, exchange rate stability in lag I \& 2 (c5 and c6) jointly has no significant impact on the rate of inflation, though it was used to reduce inflation in lag 2 by $15.7 \%$, this agrees with the previous work done by Hsing (2012). c7 and c8 representing the coefficients of financial integration in lag $1 \& 2$, jointly was used to reduce inflation significantly by $129 \%$ and $79 \%$ respectively, this supports the work done by Aizenman (2011a). While the coefficient of economic growth (c9 \& c10) have no significant impact on inflation, also financial market depth and financial institution depth respectively have no impact on the rate of inflation this supports the findings of Ogbuagu and Ewubare (2014).

Model 1b

$$
\operatorname{rgdp}_{\mathrm{t}}=\mathrm{b}_{\mathrm{ot}}+\mathrm{b}_{1} \text { exrs }_{\mathrm{t}}+\mathrm{b}_{2} \text { fini }_{\mathrm{t}}+\mathrm{b}_{3} \mathrm{Cpin}_{\mathrm{t}}+\mathrm{b}_{4} \text { smcap }_{\mathrm{t}}+\mathrm{b}_{5} \text { msup }_{\mathrm{t}}+\mu_{\mathrm{t}}
$$

Where cpin, smcap, and msup are introduced in the model as control variables, and rgdp is the dependent variable representing economic growth.

Table 2. VECM (dependent variable: $\mathrm{D}(\log g \mathrm{gdp}))$

\begin{tabular}{crcrc}
\hline \hline & Coefficient & Std. Error & t-Statistic & Prob. \\
\hline \hline C(46) & -1.616622 & 1.021862 & -1.582035 & 0.1360 \\
C(47) & -0.132507 & 0.290319 & -0.456419 & 0.6551 \\
C(48) & 0.953857 & 0.759954 & 1.255151 & 0.2300 \\
C(49) & 0.358587 & 0.626126 & 0.572707 & 0.5759 \\
C(50) & 0.309217 & 0.248278 & 1.245446 & 0.2334 \\
C(51) & 0.542528 & 0.210390 & 2.578679 & 0.0219 \\
C(52) & -0.874053 & 0.835465 & -1.046188 & 0.3132 \\
C(53) & -0.118688 & 0.994274 & -0.119372 & 0.9067 \\
C(54) & -0.134140 & 0.221036 & -0.606869 & 0.5537 \\
C(55) & 0.248736 & 0.252764 & 0.984061 & 0.3418 \\
C(56) & -0.145062 & 0.202025 & -0.718038 & 0.4845 \\
C(57) & 0.086653 & 0.214589 & 0.403807 & 0.6925 \\
C(58) & -3.227222 & 1.584388 & -2.036888 & 0.0610 \\
C(59) & 0.768983 & 1.542665 & 0.498477 & 0.6259 \\
C(60) & 0.044128 & 0.188895 & 0.233611 & 0.8187 \\
\hline \hline R-squared & 0.637378 & Mean dependent var & -0.025416 \\
Adjusted R-squared & 0.274756 & S.D. dependent var & 1.013393 \\
S.E. of regression & 0.863019 & Akaike info criterion & 2.849483 \\
Sum squared resid & 10.42721 & Schwarz criterion & 3.556705 \\
Log likelihood & -26.31750 & Durbin-Watson stat & 2.173109 \\
\hline \hline
\end{tabular}

Source: Authors e-view computation (2015)

Notably from the Table 2, c50 and c51 representing exchange rate stability coefficients in lags $1 \& 2$ have a significant positive impact on economic growth in both periods, indicating that the exchange rate stability policy in both periods was used to increase economic growth by $30 \%$ \& $54 \%$, this is in support with the studies done by( Quinn 1995, Mundel 1995, Grauwe and Schnabl 2006, Mckinnon and Schnabl 2004). While financial integration in both lags $1 \& 2$ (c52 \&c53) have a reduction impact though not significant on economic growth. 
Again coefficients of inflation, financial market depth and financial institution depth have no significant impact on the rate of growth.

Model 2a

$$
\operatorname{cpiv}_{\mathrm{t}}=\mathrm{b}_{\mathrm{ot}}+\mathrm{b}_{1} \text { exrs }_{\mathrm{t}}+\mathrm{b}_{2} \text { fini }_{\mathrm{t}}+\mathrm{b}_{3} \mathrm{gdpv}_{\mathrm{t}}+\mathrm{b}_{4} \text { smcap }_{\mathrm{t}}+\mathrm{b}_{5} \text { msup }_{\mathrm{t}}+\mu_{\mathrm{t}}
$$

Where gdpv, smcap, and msup are control variables, and cpiv is the dependent variable representing inflation volatility.

Table 3. VECM (dependent variable: $\mathrm{D}(\log$ cpiv))

\begin{tabular}{crrrr}
\hline \hline & Coefficient & Std. Error & t-Statistic & Prob. \\
\hline \hline C(1) & -0.403617 & 0.256232 & -1.575201 & 0.1348 \\
C(2) & 0.096462 & 0.115733 & 0.833485 & 0.4168 \\
C(3) & 0.091340 & 0.226910 & 0.402539 & 0.6926 \\
C(4) & 0.115997 & 0.188968 & 0.613843 & 0.5479 \\
C(5) & -0.027934 & 0.129917 & -0.215013 & 0.8325 \\
C(6) & -0.074681 & 0.101238 & -0.737679 & 0.4714 \\
C(7) & -0.250223 & 0.480767 & 0.520466 & 0.6099 \\
C(8) & -0.473388 & 0.355179 & -1.332817 & 0.2013 \\
C(9) & 0.121876 & 0.089009 & 1.369254 & 0.1898 \\
C(10) & -0.016842 & 0.087018 & -0.193543 & 0.8490 \\
C(11) & -0.290477 & 0.461796 & -0.629016 & 0.5382 \\
C(12) & 0.229607 & 0.484187 & 0.474211 & 0.6418 \\
C(13) & -0.018685 & 0.063641 & -0.293597 & 0.7728 \\
\hline \hline
\end{tabular}

Source: Authors e-view computation (2015)

From the above table, the coefficient of cointegrating models (c1) is negative but not significant, this indicate that there is no long run causality between the variables.

In the short-run, it is found that exchange rate stability, financial integration, and financial sector development has no significant impact on the inflation volatility, though exchange rate stability and financial integration policy in both lag $1 \& 2$ (c5, c6, c7 and c8) have a reduction effect on the inflation volatility, this is in line with Hsing (2012), who found that financial integration was used to reduce inflation volatility in Greece.

Model 2b

$$
\operatorname{gdpv}_{\mathrm{t}}=\mathrm{b}_{\mathrm{ot}}+\mathrm{b}_{1} \text { exrs }_{\mathrm{t}}+\mathrm{b}_{2} \text { fini }_{\mathrm{t}}+\mathrm{b}_{3} \text { cpiv }_{\mathrm{t}}+\mathrm{b}_{4} \text { smcap }_{\mathrm{t}}+\mathrm{b}_{5} \mathrm{msup}_{\mathrm{t}}+\mu_{\mathrm{t}}
$$

Where cpiv, smcap, and msup are control variables, and gdpv is the dependent variable representing growth volatility. 
Table 4. VECM (dependent variable: D(loggdpv))

\begin{tabular}{ccccc}
\hline \hline & Coefficient & Std. Error & t-Statistic & Prob. \\
\hline \hline C(46) & -0.134875 & 0.350014 & -0.385343 & 0.7058 \\
C(47) & -0.121483 & 0.077958 & -1.558323 & 0.1415 \\
C(48) & -0.156202 & 0.232599 & -0.671550 & 0.5128 \\
C(49) & -0.072192 & 0.232829 & -0.310066 & 0.7611 \\
C(50) & -0.093467 & 0.118441 & -0.789141 & 0.4432 \\
C(51) & -0.005255 & 0.131176 & -0.040062 & 0.9686 \\
C(52) & 0.358796 & 0.767929 & 0.467225 & 0.6475 \\
C(53) & -0.266894 & 0.489217 & -0.545554 & 0.5940 \\
C(54) & 0.007715 & 0.291629 & 0.026456 & 0.9793 \\
C(55) & 0.262561 & 0.371718 & 0.706344 & 0.4916 \\
C(56) & 0.128066 & 0.168796 & 0.758699 & 0.4606 \\
C(57) & 0.005974 & 0.142118 & 0.042037 & 0.9671 \\
C(58) & -0.163557 & 0.616739 & -0.265197 & 0.7947 \\
C(59) & -0.275413 & 0.596122 & -0.462008 & 0.6512 \\
C(60) & -0.098592 & 0.110338 & -0.893546 & 0.3867 \\
\hline \hline
\end{tabular}

Source: Authors e-view computation (2015)

From the above Table 4, the short - run coefficients of exchange rate stability (C50 \& C51) was used to reduce growth volatility, though not significant. And the impact of other variables on growth volatility remained insignifican.

4.1 The Impulse Response Result (IRF) for Objective (2)

The results of the Impulse Response Function (IRF), aimed at tracing the responses of the dependent variables (inflation, economic growth, inflation volatility, and output volatility) with the macroeconomic policy variables (the exchange rate stability and financial integration). Thus the result is presented as below. 
Table 5. The impulse responses of inflation and economic growth to shocks from exchange rate stability, financial integration, financial market depth, and financial institution depth

\begin{tabular}{ccccccc}
\hline \hline \multicolumn{7}{c}{ Response of logcpin: } \\
Period & LOGCPIN & LOGEXRS & \multicolumn{1}{c}{ LOGFINI } & LOGRGDP & LOGSMCAP & LOGMSUP \\
\hline \hline 1 & 0.463219 & 0.000000 & 0.000000 & 0.000000 & 0.000000 & 0.000000 \\
2 & 0.617777 & -0.197250 & 0.078564 & -0.074029 & 0.059627 & 0.013887 \\
3 & 0.395596 & -0.327513 & 0.185470 & -0.172184 & -0.078728 & 0.166047 \\
4 & 0.292045 & -0.266344 & 0.053026 & -0.083496 & 0.095105 & 0.176057 \\
5 & 0.247004 & -0.097231 & -0.183318 & -0.052312 & 0.218654 & 0.164116 \\
6 & 0.180301 & -0.073343 & -0.193562 & -0.032599 & 0.040664 & 0.127329 \\
7 & 0.195093 & -0.100271 & -0.001134 & 0.053258 & -0.031251 & -0.064235 \\
8 & 0.265382 & -0.096721 & 0.187610 & -0.060946 & 0.072590 & -0.007291 \\
9 & 0.253227 & -0.108119 & 0.115075 & -0.169446 & 0.036624 & 0.196562 \\
10 & 0.272919 & -0.159195 & -0.059591 & -0.051324 & -0.007470 & 0.092267 \\
\hline \hline & & & & & \\
& & & & & \\
Period & LOGCPIN & LOGEXRS & LOGFINI & LOGRGDP & LOGSMCAP & LOGMSUP \\
\hline \hline & & & & & \\
1 & -0.330436 & 0.145179 & -0.723439 & 0.301947 & 0.000000 & 0.000000 \\
2 & -0.363661 & 0.135991 & -0.195994 & 0.283446 & -0.104002 & -0.424570 \\
3 & -0.415623 & 0.250855 & 0.134878 & 0.098982 & 0.036997 & -0.047560 \\
4 & -0.561950 & 0.200162 & 0.103385 & 0.051380 & -0.165866 & -0.167798 \\
5 & -0.344829 & 0.213161 & 0.098998 & 0.104886 & 0.014731 & -0.181636 \\
6 & -0.529198 & 0.268349 & -0.072094 & 0.182491 & 0.009160 & -0.191909 \\
7 & -0.590490 & 0.288285 & -0.009089 & 0.181917 & -0.156863 & -0.308010 \\
8 & -0.463374 & 0.323941 & 0.020983 & 0.184998 & -0.041618 & -0.244564 \\
9 & -0.466435 & 0.287320 & -0.018120 & 0.145645 & -0.123926 & -0.246273 \\
10 & -0.370840 & 0.214082 & 0.059670 & 0.131215 & -0.135818 & -0.227811 \\
\hline \hline
\end{tabular}

Source: Own e-view computation (2015)

The Table 5 above shows the impulse response of inflation, economic growth to one standard deviation/ innovation or to a unit structural shock of exchange rate stability, financial integration, financial market depth and financial institution depth. That is our first vector error correction model.

Consequently, it is clear that when inflation produces impulse on itself, it responded by emitting positive shocks on itself at $46 \%$ and rose to $61 \%$ on the second period and fluctuated all through the remaining eight periods and never became negative. The implication is that inflation transmits a lot of positive shock to itself.

At the initial period when exchange rate stability produces impulse, the shock response on inflation is zero after which it became negative all through the periods and shows no sign of becoming positive. The implication is that strong negative shocks are emitted on inflation by exchange rate stability starting from the initial periods up to the tenth year. The response of inflation to financial integration shows that for the initial three periods, positive shocks was emitted on inflation and fluctuated for the remaining periods. The financial sector developments emitted more positive shock on inflation than negative but the impulse of inflation to economic growth shows that all through the ninth periods, negative shocks were transmitted except for the tenth that produces positive shock. This indicates that as a country is growing it became more vulnerable to price fluctuation.

The response of economic growth to shock from exchange rate stability remained positive all through the periods; the highest positive shock emitted is $32 \%$. Also economic growth response to shock from financial integration fluctuated all through the periods (for five periods it emitted negative shocks, and the other five periods it emitted positive shocks). Impulse response of economic growth from inflation shock remained negative all the periods- this has a significant negative impact in many of the periods. Beside the impulse from financial sector development on growth exhibited strong negative impact on economic growth for the ten periods under review. 
Table 6 . The impulse responses of inflation volatility and growth volatility to shocks from exchange rate stability, financial integration and financial sector development (logsmcap and logmsup)

\begin{tabular}{clllllr}
\hline \hline Periods & \multicolumn{7}{c}{$\begin{array}{c}\text { Responseoflogcpiv } \\
\text { logcpivlogexrslogfiniloggdpvlogsmcaplogmsup }\end{array}$} \\
\hline \hline & 0.300587 & 0.000000 & 0.000000 & 0.000000 & 0.000000 & 0.000000 \\
2 & 0.261336 & 0.143798 & -0.141407 & 0.040781 & 0.035294 & -0.054735 \\
3 & 0.236335 & 0.319322 & -0.321585 & 0.059354 & 0.025342 & -0.084587 \\
4 & 0.240241 & 0.349683 & -0.291958 & 0.176379 & 0.069895 & -0.148493 \\
5 & 0.187557 & 0.375938 & -0.234626 & 0.107057 & 0.010172 & -0.056215 \\
6 & 0.147578 & 0.395612 & -0.360586 & 0.230030 & 0.032907 & -0.047532 \\
7 & 0.161239 & 0.241829 & -0.332196 & 0.152962 & 0.030372 & -0.104307 \\
8 & 0.236337 & 0.341810 & -0.297083 & 0.142068 & 0.035227 & -0.132612 \\
9 & 0.295577 & 0.324532 & -0.256057 & 0.100867 & 0.031545 & -0.094077 \\
10 & 0.318874 & 0.400358 & -0.268077 & 0.126996 & 0.029914 & -0.075536 \\
\hline \hline
\end{tabular}

\begin{tabular}{ccccrrr}
\multicolumn{7}{c}{ Response of loggdpv: } \\
Period & LOGCPIV & LOGEXRS & \multicolumn{1}{c}{ LOGFINI } & \multicolumn{1}{l}{ LOGGDPV } & \multicolumn{1}{l}{ LOGSMCAP } & \multicolumn{1}{l}{ LOGMSUP } \\
\hline \hline 1 & -0.238202 & -0.031480 & -0.192821 & 0.140105 & 0.000000 & 0.000000 \\
2 & -0.225072 & -0.158065 & -0.132202 & 0.056608 & -0.011389 & -0.009103 \\
3 & -0.171298 & -0.111006 & -0.114222 & 0.031557 & -0.002385 & -0.021290 \\
4 & -0.124924 & -0.139031 & -0.077300 & 0.035016 & 0.010171 & -0.018439 \\
5 & -0.152824 & -0.089697 & -0.060222 & 0.039275 & -0.006156 & 0.005760 \\
6 & -0.225305 & -0.126729 & -0.116534 & 0.059779 & -0.007351 & 0.015587 \\
7 & -0.198458 & -0.151337 & -0.113820 & 0.060805 & 0.002715 & -0.006270 \\
8 & -0.202060 & -0.140085 & -0.095047 & 0.043333 & -0.000959 & -0.018835 \\
9 & -0.188497 & -0.122830 & -0.089553 & 0.043402 & -0.003337 & -0.003195 \\
10 & -0.180379 & -0.126099 & -0.086879 & 0.042535 & -0.003512 & 0.005139 \\
\hline \hline
\end{tabular}

Source: Own e-view computation (2015)

From the result, the impulse response of inflation volatility on itself indicates that positive shocks were emitted for the tenth periods. Exchange rate stability emitted positive shock on inflation volatility for the periods under review, while impulse from financial integration and financial institution depth (logmsup) to inflation volatility remained negative all through the year. On the other hand shock from output volatility and financial market depth indicates strong positive impulses on inflation volatility.

Furthermore, the impulse of growth volatility on itself produces positive shock on itself for the periods under review. The response of growth volatility to exchange rate stability and financial integration shows that negative shocks are emitted. Also inflation volatility emitted strong negative impulse on growth volatility, financial market depth transmit negative impulse on growth volatility. And finally, the impulse of exchange rate stability to shocks from inflation volatility, growth volatility and financial market depth remained negative for the tenth periods (see appendix for result). Impulse response of financial integration to shocks from inflation volatility, growth volatility and financial market development emitted negative shocks.

\subsection{Policy Implications}

Exchange rate stability from our result has no significant impact on inflation, inflation volatility and growth volatility, though it was used to reduced the rate of inflation in lag2, the rate of inflation volatility and growth volatility in both lags. The level of achievement in exchange rate stability has a significant increase impact on economic growth rate, this agrees with our economic expectation. And it is in line with Aizenman (2011a). Grauwe and Schnabl (2006) finds significant impact of exchange rate stability on low inflation as well as a highly significant positive impact of exchange stability on real growth, again Mckinnon and Schnabl (2004) finds that exchange rate stability contributed to low and stable inflation in East Asia and this consequently contributed to increased investment and economic growth. Hsing (2012) finds that more exchange rate stability does not affect the inflation rate, the growth rate, inflation volatility and output volatility in Greece. This is a contrary result to Aizenman et al., (2008b) who used a 
large sample including Greece to indicate that more exchange rate stability results in higher inflation and output volatility. Therefore, this implies that the extent of achievement in stabilizing exchange rate in Nigeria has reduction effect in inflation rate, inflation and growth volatility but not significant and has been used to significantly increase economic growth.

While the level of achievement in financial integration has a strong significant impact on inflation and no significant impact on economic growth, inflation volatility, and growth volatility though was used to reduce economic growth, inflation volatility, and output volatility in lag 2.

This strongly indicates that the extent of achievement in exchange rate stability and financial integration as policy variables have not impacted positive impulses on the rate of inflation, this could be as a result of inappropriate exchange rate management in Nigeria which according to Osaka, Masha and Adamgbe (2003) has impacted negatively on overall macroeconomic management in several ways. Beside economic growth emitted negative shocks to inflation and inflation negative impulse on economic growth, showing that as Nigeria is growing, there is a need for the economy to pursue policies that will encourage more exchange rate stability and financial integration. The more stable the economy became, the more she will achieve when open to the rest of the world. The interconnectivity between exchange rate stability and financial openness is a very strong one.

\subsection{Result of Econometric Procedural Test}

Shows that there is no autocorrelation, no heteroscedasticity and the models are normally distributed except model $1 \mathrm{~b}$.

\subsection{Conclusion / Policy Recommendation}

The main objective of this study is to find out how the extent of achievement in exchange rate stability and financial integration through the lens of trilemma has impacted on inflation, economic growth and inflation and growth volatility. One result is outstanding; exchange rate stability has a significant impact on economic growth in the short run and at same time emitted strong positive shock on economic growth, it also emitted strong positive impact on inflation volatility and was used to reduce inflation volatility in the short run though not significant. On the other hand, financial integration has a significant reduction impact on inflation and was used to reduce inflation volatility but not significant.

Again exchange rate stability and financial integration has no significant impact on growth volatility, the responses of growth volatility to exchange rate stability and financial integration shows that negative shocks are emitted, rather inflation volatility emitted negative shock on growth volatility and exchange rate stability and financial integration response to shocks from inflation volatility, growth volatility and financial market depth remained negative. This shows that the causes and consequences of macroeconomic volatility has been pointed out by scholars to come majorly from financial crises experienced by the developing countries over the past years. Such crises are extra manifestations of volatility and are associated with rapid opening up to global trade and financial linkages (Ramey and Ramey 1995).

There are various direct and indirect theoretical channels through which increased financial flow can enhance growth and reduce inflation. The direct channels include argumentation of domestic savings through diversification of production base to enhance export sector, reduction in the cost of capital through better global allocation of risk, development of financial sector and enhanced technical know-how. The indirect channels are associated with promotion of trade specialization and inducement for better economic policies for example appropriate exchange rate, monetary and fiscal policies (Levine 1996, Kalenilio-Zean, Sorensen). Finally, the issue of socio-economic, religious and political instability should be re-examined.

Further study; we recommend that the impact of the policy combination of financial integration and monetary independency in Nigeria be examined by future researchers.

\section{References}

Aizenman, J., \& Ito, H. (2011a). The 'Impossible Trinity,' the International Monetary Framework, and the Pacific Rim. Forthcoming. In I. N. Kaur and N. Singh (Eds.), Handbook of the Economics of the Pacific Rim. Oxford University Press.

Aizenman, J., \& Ito, H. (2011b). Trilemma Policy Convergence Patterns and Output Volatility. Manuscript, UCSC.

Aizenman, J., \& Ito, H. (2012). Trilemma Policy Convergence Patterns and Output Volatility. NBERworking paper, NBER, January.

Aizenman, J., Chinn, M. D., \& Ito, H. (2008a). The "Impossible Trinity" Hypothesis in an Era of Global Imbalances: Measurement and Testing. UCSC \& the NBER University of Wisconsin \& the NBER Portland State University, November 29. 
Aizenman, J., Chinn, M. D., \& Ito, H. (2008b). Assessing the Emerging Global Financial Architecture: Measuring the Trilemma's Configurations over Time. NBER WORKING PAPER SERIES, Working Paper 14533. Retrieved from http://www.nber.org/papers/w14533

Aizenman, J., Chinn, M. D., \& Ito, H. (2010). The Emerging Global Financial Architecture: Tracing and Evaluating the New Patterns of the Trilemma's Configurations. Journal of International Money and Finance, 29, 615-641. http://dx.doi.org/10.1016/j.jimonfin.2010.01.005

Aizenman, J., Chinn, M. D., \& Ito, H. (2011a). Surfing the Waves of Globalization: Asia and Financial Globalization in the Context of the Trilemma. Journal of the Japanese and International Economies, 25, 290-320. http://dx.doi.org/10.1016/j.jjie.2011.06.003

Aizenman, J., Chinn, M. D., \& Ito, H. (2011b). The Trilemma Indexes. Retrieved from http://web.pdx.edu/ ito/trilemma_indexes.htm

Alexiou, C. (2011). When the Bough Break: Making Sense of the Greek Economic 'Waterloo'. International Journal of Economics and Financial Issues, 1(3), 123-132. Retrieved from http://www.cranfield.ac.uk/citations/\%3Fid\%3D8282

Bailliu, J., Robert, L., \& Jean-Francois, P. (2003). Does Exchange Rate Policy Matter for Growth?. International Finance, 6(3), 381-414. http://dx.doi.org/10.1111/j.1367-0271.2003.00123.x

Boyd, J., \& Smith, B., (1992). Intermediation and the Equilibrium Allocation of Investment Capital: Implications for Economic Development. Journal of Monetary Economics, 30, 409-432. http://dx.doi.org/10.1016/0304-3932(92)90004-L

Calvo, G., \& Frederic, M (2003). The Mirage of Exchange Rate Regimes for Emerging Market Countries. Journal of Economic Perspectives, 17(4), 99-118. http://dx.doi.org/10.1257/089533003772034916

Central Bank of Nigeria Statistical Bulletin. (2006). 17, 246.

Chinn, M. D., \& Ito, H. (2006). What Matters for Financial Development. Capital Controls, Institutions, and Interactions. Journal of Development Economics, 81, 163-192. http://dx.doi.org/10.1016/j.jdeveco.2005.05.010

Chinn, M. D., \& Ito, H. (2008). A New Measure of Financial Openness. Journal of Comparative Policy Analysis, 10, 309-322. http://dx.doi.org/10.1080/13876980802231123

De, G., \& Schnabl, G. (2008). Exchange Rate Stability, Inflation and Growth in (South) Eastern and Central Europe. Social Science Research Network, 1-33, SSRN-ID946968. Retrieved from http://www.aeefi.com/RePEc/pdf/defi14-02.pd

Edison, H. J., Klein, M. W., Ricci, L., \& Sløk, T. (2002). Capital Account Liberalization and Economic Performance: A Review of the Literature. IMF Working Paper. Washington, D.C.: International Monetary Fund (May). Retrieved from https://www.u-picardie.fr/eastwest/fichiers/art66.pdf

Eichengreen, B. J. (2001). Capital Account Liberalization: What Do Cross Country Studies Tell Us? The World Bank Economic Review, 15, 341-365. http://dx.doi.org/10.1093/wber/15.3.341

Elder, J. (2004). Another perspective on the effects of inflation uncertainty. Journal of Money Credit and Banking, 36, 911-28. http://dx.doi.org/10.1353/mcb.2004.0073

Frankel, J., \& Andrew, R. (2002). An Estimate of the Effect of Common Currencies on Trade and Income. Quarterly Journal of Economics, 117, 437-66. http://dx.doi.org/10.1162/003355302753650292

Frieden, J. A. (1991). Invested Interests: The Politics of National Economic Policy in a World of Global Finance. International Organization, 45, 425-451. http://dx.doi.org/10.1017/S0020818300033178

Friedman, M. (1953). The Case for Flexible Exchange Rates. In Milton Friedman (Ed.), Essays of Positive Economics. Chicago: University of Chicago Press.

Ghosh, A., Anne-Marie, G., \& Holger, W. (2003). Exchange Rate Regimes: Choices and Consequences. Cambridge, Massachusetts: MIT Press.

Grier, R., \& Grier, K. B. (2006). On the Real Effects of Inflation and Inflation Uncertainty in Mexico. Journal of Development Economics, 80,478-500. http://dx.doi.org/10.1016/j.jdeveco.2005.02.002

Harendra, B., \& Rajiv, R. (2009). Dynamics of Financial Globalization and Growth: Some Evidence from Emerging Market Economies. Reserve Bank of India. Occasional Papers, 30(2).

Hutchison, M., Sengupta, R., \& Singh, N. (2012). India's Trilemma; Financial Liberalization, exchange rate and Monetary Policy. The World Economy, 35(10), 3-18. http://dx.doi.org/10.1111/j.1467-9701.2011.01381.x 
International Monetary Fund. (2012). Liberalization and management of capital flows: An Institutional view. Washington DC: International Monetary Fund.

Kalemli-Ozean, S., Bent, S. \& Yosha, O. (2003). Risk Sharing and Insdustrial Specialization; Regional International Evidence. American Economic Review, 93(3), 903. http://dx.doi.org/10.1257/000282803322157151

Kaminsky, G., \& Schmukler, S. L. (2002). Short-Run Pain, Long-Run Gain: The Effects of Financial Liberalization. World Bank Working Paper No. 2912; IMF Working Paper No.0334. Washington, D.C.: International Monetary Fund (October). http://dx.doi.org/10.1596/1813-9450-2912

Kose, M. A., Eswar, P., Kenneth, R., \& Wei, S-J. (2006). Financial Globalization: A Reappraisal. IMF Working Paper. http://dx.doi.org/10.5089/9781451864496.001

Levine, R. (1996). Foreign Banks, Financial Development and Economic Growth. In International Fiance Markets; Harmonization Versus Competition (pp. 24-54). Washington: AEI Press.

Levine, R. (1997). Financial Development and Economic Growth: Views and Agenda. Journal of Economic Literature, 35(2), 688-725.

Levine, R. (2004). International financial liberalization and economic growth: Views and Agenda. Journal of Economic Literature, 35(2), 688-726.

Lewis, K. K. (1999, June). Trying to Explain Home Bias in Equities and Consumption. Journal of Economic Literature, 37, 571-608.

Lothian, J. (2000). Capital Market Integration and Exchange Rate Regimes in Historical Perspective. New York: Elsevier Science, Inc.

McKinnon, R., \& Gunther, S. (2004). The East Asian Dollar Standard, Fear of Floating, and Original Sin. Review of Development Economics, 8(3), 331-60. http://dx.doi.org/10.1111/j.1467-9361.2004.00237.x

Meade, J. (1951). The Theory of International Economic Policy. London: Oxford University Press.

Mundell, R. (1973a). A Plan for a European Currency. In Harry Johnson and Alexander Swoboda (Eds.), The Economics of Common Currencies. London: Allen and Unwin.

Mundell, R. (1973b). Uncommon Arguments for Common Currencies. In Harry Johnson and Alexander Swoboda (Eds.), The Economics of Common Currencies. London: Allen and Unwin.

Mundell, R. (1995). Exchange Rate Systems and Economic Growth. Rivista de Politica Economica, 85, 1-36.

Nnana, O. (2002). Monetary and Financial Sector Policy Measures in the 2002 Budget. A Paper Presented at CBN/NCEMA/NES Seminar on the 2002 Federal Budget, Lagos, May 7. Retrieved from http://www.econjournals.com/index.php/ijefi/article/download/67/pd

Obadan, M. I. (1996). Overview of Exchange Rate Mnangement in Nigeria from 1986 to Date. The Dynamics of Exchange Rate in Nigeria - Central Bank of Nigeria, 30(3), 1-11. Retrieved from http://www.cenbank.org/OUT/PUBLICATIONS/BULLION/GOV/2007/BULL\%2520JUL-SEPT06.PDF

Obstfeld, M. (1994). Risk- Taking, Global Diversification, and Growth. American Economic Review, 9(4), 73-96. Retrieved from https://ideas.repec.org/p/nbr/nberwo/4093.html

Ogbuagu, A., \& Ewubare, D. (2014). Financial Deepening and Inflation in Nigeria: An Open Economy Model Approach. Journal of Economics and Sustainable Development, 5(25), 39-50. Retrieved from http://www.iiste.org/Journals/index.php/JEDS/article/download/17525/17909

Ramey, G., \& Ramey, V. (1995). Cross Country Evidence on the Link Between Volatility and Growth. American Economic Review, 85(5), 1138-51.

Suranovic, S. (2000). International Finance Theory and Policy. Retrieved from http://internationalecon.com/finance/fch110/f110-4.php

Wang, P., Wein, Y., \& Zhiwei, X. (2008). Two Way Capital Flows and Global Imbalaces: A Neoclassical Approach. Working Paper, Federal Reserve Bank of St. Louis, 49(6), 566-588.

World Bank. (2012). Global Financial Development Report 2013: Rethinking the Role of the State in Finance. World Bank, Washington, DC. Retrieved from http://www.worldbank.org/financialdevelopment 